\title{
NOTES ON THE START DATE OF THE POIENEȘTI-LUCAȘEUCA CULTURE
}

\begin{abstract}
In this study, we analyse the issue of the start date of the PoieneștiLucașeuca culture. Based on the dating of certain categories of items discovered in both funerary and habitation sites but also on the information supplied by certain written sources we set the chronological limit of this culture to the last quarter of the 3rd century BC.
\end{abstract}

Keywords: the Carpathian-Dniester forest steppe, recent pre-Roman Iron age, the Poienești-Lucașeuca culture, chronology.

A s proven by the archaeological finds, during the last decades of the 3rd century BC in the east-Carpathian area occurred a series of ethno-cultural, socio-economic and political changes which resulted in the establishment of the Poienești-Lucașeuca ${ }^{1}$ culture (hereinafter P-L) in the Carpathian-Dniester forest steppe.

Archaeological investigations, both systematic excavations and field research performed in the last six decades in several sites ascribed to the P-L culture, like those at Borosești ${ }^{2}$, Botoșana ${ }^{3}$, Dolheștii Mari ${ }^{4}$, Ghelăiești ${ }^{5}$, Lozna Hlibicoc $^{6}$, Lucașeuca ${ }^{7}$, Poienești ${ }^{8}$ and Orheiul Vechi ${ }^{9}$ (fig.), supplied important data which improved the knowledge of this cultural aspect. Nonetheless, these remains raise key issues, like for instance their origin and chronology that are incompletely resolved, in the specialty literature debates being still ongoing ${ }^{10}$.

One of the less clarified issues is that of the start date of the P-L culture, hence we decided to discuss this topic herein. Firstly, we shall briefly present the most important views on this matter.

In a first stage of the research, the excavator of the eponymous cemetery at Poienești, R. Vulpe, dated the begging of the P-L type cemetery around 200 $\mathrm{BC}^{11}$. On the other hand, the author of the archaeological investigations in the cemetery and settlement at Lucașeuca, G.B. Fedorov, placed the lower

\footnotetext{
BABEȘ 1985; TEODOR 1987; TEODOR 1992; BABEȘ 1993; MUNTEANU 1995; BABEȘ 2003; MUNTEANU 2004; IARMULSCHI 2013.

2 BABES 1993, 183-192.

3 TEODOR 1980.

4 ANDRONIC 1994.

BABES 1969.

6 TEODOR 1992.

7 ФЕДОРОВ 1960

8 VULPE 1953; BABES 1993, 208-214.

9 POSTICĂ/MUNTEANU 1999 .

10 BABES 1985; TEODOR 1992; CONOVICI 1992; BABEȘ 1993; TKAYУK 1999; BABES 2003; MUNTEANU 2004; ПАЧKOBA 2006; IARMULSCHI 2013.

11 VULPE 1953, 490-494; VULPE 1955, 107.
}

\section{Vasile larmulschi}

Freie Universität Berlin, Institut für Prähistorische Archäologie 
chronological limit of these sites by early 2 nd century $\mathrm{BC}^{12}$.

At his turn, the well-known Bucharest-based scholar M. Babes set the start of the culture in the first half of the 2nd century $\mathrm{BC}^{13}$ or the interval between 200-175 $\mathrm{BC}^{14}$. In his last studies, the author places the lower chronological limit of the culture around $200 \mathrm{BC}^{15}$.

The analysis of the stamps on the Greek amphorae within the environment of respective culture as well as the discovery of P-L type pottery in level IV of the Getae fortress at Satu Nou Valea lui Voicu, made N. Conovici date the start of the culture to the last two decades of the $3 r d$ century $\mathrm{BC}^{16}$, idea also expressed by O. Munteanu ${ }^{17}$.

Within the context of specifying the lower chronological limit of the P-L culture, it is also worth mentioning V. E. Eremenko's view, who based on the association of inventory pieces in the cemetery at Poienești, set the start of the culture to the last quarter of the 3rd century $\mathrm{BC}^{18}$. Practically similar conclusions also reached V. Iarmulschi, who dated the start of the P-L cultural aspect to the last two decades of the 3 rd century $\mathrm{BC}^{19}$.

Given the archaeological finds in both cemeteries and habitation sites but also the information supplied by literary sources we shall attempt below to express once more our view on this topic.

As mentioned in the specialty literature, one of the earliest sites ascribed to the P-L culture is represented by the eponymous cemetery at Poienești ${ }^{20}$. The oldest graves in this cemetery - G. 3, 105, 340, 390, 392, 434, 535, 556 and $572^{21}$ - contain in the chronologically relevant inventory the following items: brooches type II.2, II.5 and belt fittings of type III.3 (Babes, typology) 22 .

The brooches with bronze bow spheres (Babeș type II.5) (fig. 2,2) are one of the earliest dating elements of the P-L culture. Such dress accessories are frequent in the Cimbrian Peninsula and date to stage IIA of the pre-Roman Iron age in Martens's chronology ${ }^{23}$. Such brooches are also known in the islands of Bornholm, Fühnen and Gotland ${ }^{24}$, where they mark the start of the recent pre-Roman Iron age, which in absolute date corresponds to the last decades of the 3rd century $\mathrm{BC}^{25}$.

The presence of such brooches in the area east of the Eastern Carpathians during the last quarter of the 3rd century $\mathrm{BC}$ is also proven by the recent finds in the Scythian barrow cemetery at Hlinoie ${ }^{26}$. The excavators date though the brooches with bow spheres identified in the site there between the second quarter of the 3rd century BC and early

\footnotetext{
ФЕДОРОВ 1960, 25.

BABEȘ 1985, 201-202.

BABES 1993, 153.

BABEȘ 2001, 522; BABEȘ 2003, 237.

CONOVICI 1992, 3-12; CONOVICI 1996, 369-372.

MUNTEANU 1995, 24-25.

EPEMEHKO 1997, 114.

IARMULSCHI 2013, 41.47

BABEȘ 1993, 131-134.145; EPEMEHKO 1997, 114; BABEȘ 2010, 545; IARMULSCHI 2013, 32.

21 BABEȘ 1993, 132-133, Abb. 33; IARMULSCHI 2013, 31-32, Fig. 3.

22 See BABES 1993, 59-118.

23 MARTENS 1996, 234, Abb. 12.

24 BIEGER 2003, 37-46.

25 BRANDT 2001, 85-87; BIEGER 2003, 86-87.

26 ТЕЛНОВ/ЧЕТВЕРИКОВ/СИНИКА 2016, 889, 956, Fig. 442/16.
}

2nd century $\mathrm{BC}^{27}$, which we believe is not precisely accurate. As specified in the specialty literature ${ }^{28}$ such brooches are dated mainly to the last decades of the 3rd century BC. In fact, such chronological framing is further confirmed by the finds in G 31/1 at Hlinoie, where beside such a brooch ${ }^{29}$ (fig. $2,13)$ was also found a Synopean amphora, bearing on handle

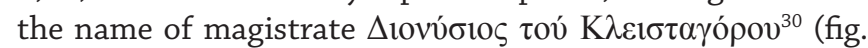
2,12). The activity of this eponymous was placed between mid 10'ies of the 3rd century - the 90'ies of the 2nd century $\mathrm{BC}^{31}$.

Relevant for dating the early stage of the cemetery at Poienești and, implicitly, the start of the P-L culture are brooches of type II.2 and belt fittings of type III.3 (fig. 2,1.5). We mention that in the Getae cemetery at Zimnicea a brooch similar to type II.2 was found in grave C10G108 ${ }^{32}$. Respective complex was placed to horizon IV of the site (ca. 230/225$100 \mathrm{BC}$ ), more precisely during an initial phase of this stage $^{33}$. In the Celtic cemetery at Male Kosihy such brooches were broadly dated to the $3 \mathrm{rd}-2$ nd centuries $\mathrm{BC}^{34}$, while in the cemetery at Piscolt such specimens were framed by the end of LT C1 - early LT C $2^{35}$, respectively the last quarter of the 3rd century - early decades of the 2 nd century $\mathrm{BC}^{36}$.

To the end of the 3rd century $B C$ also leads the chronological framing of type III.3 belt fittings. We specify that within the sites on the mid course of the Elbe, such pieces are commonly dated to LT C1/C2 ${ }^{37}$, while in Pomerania - to phase II.a, according to Reinecke ${ }^{38}$.

Therefore, based on the earliest pieces discovered in the eponymous cemetery at Poienești, we set the lower chronological limit to the last quarter of the 3rd century BC. Now, let us see what kind of information is supplied by the habitation sites on this matter.

In terms of settlements, they commonly contain little datable materials. Most often, the chronologically relevant remains within the $\mathrm{P}-\mathrm{L}$ settlements are represented by Hellenistic amphorae. Within the environment of said culture, such finds were reported in 37 habitation sites ${ }^{39}$. Important for the discussion herein is that some handle fragments preserve the stamps containing the name of the magistrate or producer, both being highly relevant for dating such sites by analogy with the Greek world.

Thus, one of the earliest settlements ascribed to the P-L aspect seems that at Roșiori Dulcești. We mention that from L. 1 at Roșiori Dulcești comes the fragment of a Synopean handle, orange, bearing the stamp of magistrate

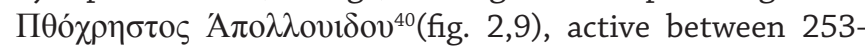
$252 \mathrm{BC}^{41}$. Since in the same complex was discovered a base

\footnotetext{
27 ТЕЛНОВ/ЧЕТВЕРИКОВ/СИНИКА 2016, 957.

28 BIEGER 2003, 86-87.

29 ТЕЛНОВ/ЧЕТВЕРИКОВ/СИНИКА 2016, 216.

ТЕЛНОВ/ЧЕТВЕРИКОВ/СИНИКА 2016, 215, Fig. 105/4-5.

КАЦ 2007, 436; ТЕЛНОВ/ЧЕТВЕРИКОВ/СИНИКА 2016, 957.

2 ALEXANDRESCU 1980, 30.

33 MĂNDESCU 2010, 179, Fig. 24.

${ }^{4}$ BUJNA 1995, Pl. 3316.

35 NÉMETI 1989, 128, Fig. 19/16; ZIRRA 1997, 117, Fig. 24/21.

${ }^{36}$ For the absolute chronology of the La Tène period see - GEBHARD 1989; ЩУКИН 1994; BRANDТ 2001

37 MÜlLER 1985, 84, Abb. 13.

38 REINECKE 1988, Taf. 4.

39 BABES 1993, 72; IARMULSCHI 2012, 195.

40 HÂNCEANU 2016, 44-45, Pl. XX,6.

${ }^{41}$ GARLAN 2004, 83, Tab. IV.
} 
of a Rhodian amphora, specific to recipients of the second half of the 3rd century BC, of which a spindle weight was made $^{42}$ (fig. 2,10), this complex was dated to the second half of the $3 r d$ century $\mathrm{BC}^{43}$. Therefore, we believe that respective site was established no later than the last decades of the 3rd century BC.

To the earliest settlements of P-L type also belongs the site at Lunca Ciurei ${ }^{44}$. Among the materials which support such view count, firstly, two handles of Rhodian amphorae bearing the name of magistrate Xenophantos I ${ }^{45}$ (fig. 2,78). The activity of this eponymous was framed to period IIb (219-210 BC), according to Finkielsztejn ${ }^{46}$.

In the site at Gorošovo ${ }^{47}$ we are dealing with an inhabitancy which very likely started also in the last quarter of the 3rd century BC. We specify that in L. 1 and L. 8 in this settlement were discovered fragments of sapropelite bracelets $^{48}$ (fig. 2,6). Such jewellery is specific in the CentralEuropean Celtic world to LT B2/C1 ${ }^{49}$. Based on these data, we believe that the site was established in a period when such items were still fashionable, respectively LT C1b, which in absolute data corresponds to the last quarter of the 3rd century - first quarter of the 2 nd century $\mathrm{BC}^{50}$.

It is possible that the site at Dănești La Meri ${ }^{51}$ was also established in the last quarter of the 3rd century BC. This is supported by the discovery in the site of a brooch made of a single bronze wire with bilateral spring of four coils, outer chord, extended body and foot attached to the bow, just below its junction, through a socket ${ }^{52}$ (fig. 2,3), specific to $\mathrm{LT} C 1^{53}$.

Among the earliest settlements of P-L type may also be deemed the settlement at Borniș ${ }^{54}$, as proven by the brooch of type III. $1^{55}$ (fig. 2,4), specific to the first two phases of the culture $^{56}$ and the Rhodian amphora fragment discovered still there $^{57}$ (fig. 2,11). We mention that the amphora fragment was imprinted with the name of magistrate Xenophanes ${ }^{58}$. Based on known associations, his activity was placed between 202-201 $\mathrm{BC}^{59}$ or $189 \mathrm{BC}^{60}$.

Thus, taking into account the finds in the eponymous cemetery at Poienești as well as some of the habitation sites, we believe that the lower chronological limit of the P-L culture must be set in last two decades of the 3rd century BC. Our view is supported by some literary sources (PseudoSkymnos, v. 797), who mentions the Bastarnae by the Lower

\footnotetext{
${ }^{42}$ HÂNCEANU 2016, 45, 48.

43 HÂNCEANU 2016, 48

44 TEODOR 1987; BABEȘ 1993, 204-206.

45 MATEEVICI 2009, 269, cat. no. 5-6.

${ }^{46}$ FINKIELSZTEJN 2001, Tab. 18.

47 ПАЧКОВА 1983.

48 ПАЧКОВА 1983, 17,29,30, Fig. 12,7-9; IARMULSCHI 2013, 44.

49 BUJNA 1982, 331; IARMULSCHI 2013, 45.

${ }^{50}$ ЩУКИН 1994, 116; IARMULSCHI 2013, 45.

51 ZAHARIA/BURAGA 1979, 245.

52 ZAHARIA/BURAGA 1979, 245, Fig. 2/6; TEODOR 1988, 43, Fig. 5/4;

BABEȘ 1993, 90, Taf. 44/21.

53 ČIŽMAR 1975, 429, Abb.8; BRANDT 2001, 57-58, Abb. 11a/2.

${ }^{54}$ POPOVICI 1981-1982.

55 The author of the find ascribed erroneously the brooch to the RomanByzantine period - POPOVICI 1988, 250.

${ }^{56}$ BABES 1993, 142, Abb. 44; IARMULSCHI 2013, 40.

57 POPOVICI 1981-1982, 155, Fig. 2; POPOVICI 1988, Fig. 1/1.

58 POPOVICI 1981-1982, 155

59 CONOVICI 1992, 10; MUNTEANU 2004, 148.

${ }^{60}$ FINKIELSZTEIJN 2001, Tab. 19.
}

Danube in the last quarter of the $3 r d$ century $\mathrm{BC}^{61}$. Very likely, in relation to the same date may be placed the Olbian decree in honour of Protogenes, should we deem those Galatii and Scirii ${ }^{62}$ as the Bastarnae recorded by the written sources. Furthermore, as also mentioned in the specialty literature ${ }^{63}$, the Barbarian tribes north the Danube, who left the remains of the P-L culture and were summoned by the kings of Macedonia, Philip V (Titus Livius, XL, 57,2) and Perseus (Plutarch 12) to aid the resolution of certain external affairs of their kingdom, were at the time well established in the east-Carpathian region, and, likely, acted in such manner that their power was recognized.

Within the same context we mention that, very likely, once they reached the Carpathian-Dniester forest steppe, the Bastarnae tribes had to fight the local population ${ }^{64}$. Both archaeological traces - the destruction of the Getae fortifications, which likely ceased to function in the last quarter of the 3rd century $\mathrm{BC}$, one of the reasons being the entry into the central and northern regions of Moldova of the Bastarnae tribes ${ }^{65}$ - and the written sources - the clashes with Oroles (Trogus Pompeius XXXII,3,16) - suggest this.

Summarizing the above, we believe that the lower chronological limit of the P-L culture should be set to the last quarter of the 3rd century $\mathrm{BC}$, both the archaeological materials (brooches of type II.2, II.5, belt fittings of type III.3, the sapropelite bracelets, the amphora material etc) and written sources (for instance Pseudo-Skymnos), who mentions the Bastarnae to the north of the Lower Danube in this period support such argument.

\section{REFERENCES}

\section{ALEXANDRESCU 1980}

Alexandrescu, A. D., La nécropole gète de Zimnicea, Dacia N. S. XXIV, 19-126.

ANDRONIC 1994

Andronic, M., Așezarea din sec. II-I î.H. de la Dolheştii Mari-Suceava, Memoria Antiquitatis XIX, 235-242.

\section{ARNĂUT 2003}

Arnăut, T., Vestigii ale sec. VII-III a.Chr. în spaţiul de la răsărit BABES 1969 de Carpaţi (Chişinău).

Babeş, M., Noi date privind arheologia şi istoria bastarnilor. O „fibulă pomeraniană” descoperită la Ghelăieşti, Studii și

${ }^{61}$ CONOVICI 1992, 11-12; MUNTEANU/IARMULSCHI 2005, 19 IARMULSCHI 2013, 47.

62 Entirely erroneous, in our view, is the assertion of Ju. A. Vinogradov and K. K. Marčenko that, archaeologically, the Scirii - recorded in the Olbian decree in honour of Protogenes - may be identified with the Tiraspol cultural group - ВИНОГРАДОВ/МАРЧЕНКО 2014, 153. Тo this effect, we wish to underline that, as early as almost five decades ago, M. Babes mentioned that the Scirii are very likely a tribe akin to the Bastarnae. They, according to the Bucharest-based researcher, beside other tribes from the north of Central Europe, like for instance the Peucinii, Sidonii and Atmonii recorded by the ancient written sources (STRABON VII, 3,17), must be identified with the P-L cultural aspect - BABEȘ 1969, 214; BABEȘ 1993, 169; BABEȘ/COMAN 2005,147 . For the issue of the ethno-cultural origin of the Tiraspol group see ТЕЛНОВ/ЧЕТВЕРИКОВ/СИНИКА 2016.

${ }^{63}$ CONOVICI 1996, 371; MUNTEANU/IARMULSCHI 2005, 18; IARMULSCHI 2013, 47.

${ }^{64}$ It is important to underline that in the specialty literature there is the view that between the Getae culture and the P-L cultural aspect there is a chronological gap of at least one century quarter see ЩУКИН 1994; ТКАЧУК 1999. The issue of the continuity/discontinuity in LT C1 shall be discussed in another study.

65 ZANOCI 1998, 111; ARNĂUT 2003, 166; HAHEU 2008, 55. 
Cercetări de Istorie Veche 20/2, 195-218.

BABEȘ 1985

Babeş, M.,Date arheologice şi istorice privind partea de nord-est a Daciei în ultimele secole î.e.n., Studii și Cercetări de Istorie Veche și Arheologie 36, 3, 183-214.

BABES 1993

Babeș, M., Die Poieneşti-Lukaševka-Kultur. Ein Beitrag zur Kulturgeschichte im Raum östlich der Karpaten in den letzten Jahrhunderten vor Christi Geburt (Bonn: Saarbrücker Beiträge zur Altertumskunde 30).

BABEȘ 2001

Babeș, M., Spaţiul carpato-dunărean în secolele III-II a.Chr. In: M. Petrescu-Dîmboviţa/A. Vulpe (ed.), Istoria românilor I (Bucharest: Editura Enciclopedică), 501-531.

BABEȘ 2003

Babeș, M., Die Poieneşti-Lukaševka-Kultur. RGA 23 (BerlinNew York), 230-239.

BABEȘ/COMAN 2005

Babeș, M./Coman, R., Practici funerare prelungite în spațiul carpato-dunărean în secolele V-III a.Chr, Arheologia Moldovei XXXIV, 103-149.

BIEGER 2003

Bieger, A., Kugelfibeln. Eine typologisch-chronologische Untersuchung zu den Varianten F, $N$ und $O$ von Beltz (Bonn: Habelt).

BRANDT 2001

Brandt, J., Jastorf und Latène. Kultureller Austausch und seine Auswirkungen auf soziopolitische Entwicklungen in der vorrömischen Eisenzeit (Rahden/Westf: M. Leidorf).

BUJNA 1982

Bujna J., Speigelung der Sozialstruktur auf latènezeitlichen Gräberfeldern im Karpatenbecken, Památky Archeologiscké 83, 312-431.

BUJNA 1995

Bujna, J., Male Kosihy - Latènezeitliches Gräberfeld. Katalog (Nitra: Archeologický ústav slovenskej akadémie vied).

\section{ČIŽMAR 1975}

Čižmar, M. Relatvní chronologie keltských pohřebišt na Moravě, Památky Archeologiscké 66, 417-437.

CONOVICI 1992

Conovici, N., Noi date arheologice privind începuturile culturii Poieneşti-Lukaševka şi prezenţa bastarnilor în Dobrogea, Studii și Cercetări de Istorie Veche și Arherologie 43/1, 3-14.

CONOVICI 1996

Conovici, N., Pe marginea unei recenzii, Studii și Cercetări de Istorie Veche și Arherologie 47/4, 369-273.

FINKIELSZTEIJN 2001

Finkielszteijn, G., Chronologie détaillée et révisée des éponymes amphoriques rhodiens de 270 à 108 av. J.-C. Premier bilan. British Archaeological Reports, International Series 990 (Oxford: Archaeopress).

GARLAN 2004

Garlan, Z., Les timbre céramiques sinopeens sur amphores et sur tuiles trouvés à Sinope. Présentantion et cataloque. Varian Anatolica XVI (Paris: de Boccard).

GEBHARD 1989

Gebhard, R., Der Glasschmuck aus dem Oppidum von Manching. Ausgrabungen in Manching 11 (Stuttgart: Steiner).

HAHEU 2008

Haheu, V., Sisteme de fortificaţii traco-getice de la est de Carpaţi (Chișinău: Academia de Ştiinţe a Moldovei, Institutul Patrimoniului Cultural, Centrul de Arheologie).

HÂNCEANU 2016

Hânceanu, G. D., Vestigii dacice și bastarne dintr-o locuință a sitului de la Roșiori-Dulcești, In: Mămălucă, M (ed.), Historica et archaelogica in honorem Ion Ioniță octogenri. Acta Musei Tutovensis XII/2 (Bârlad).

IARMULSCHI 2012

Iarmulschi, V., Amfore greceşti descoperite în mediul culturii Poieneşti-Lucaşeuca, Tyragetia XXI/1, 195-206.

IARMULSCHI 2013

Iarmulschi, V., Unele consideraţii privind cronologia culturii Poieneşti-Lucaşeuca, Tyragetia XXII/1, 29-52.

\section{MARTENS 1996}

Martens, J., Die vorrömischen Eisenzeit in Südskandinavien. Probleme und Perspektiven, Prähistorische Zeitschrift 71/2, 217-243.

MATEEVICI 2009

Mateevici N., Unele modificări privind datarea ştampilelor amforistice ale Rhodosului descoperite în mediul barbar al spaţiului nord-vest pontic, Tyragetia XVIII/1, 267-276.

MĂNDESCU 2010

Măndescu, D., Cronologia perioadei timpurii a celei de- $a$ doua epoci a fierului (sec. V-III a.Chr.) între Carpați, Nistru şi Balcani (Brăila: Istros).

\section{MUNTEANU 1995}

Munteanu O., Autohtonii în spaţiul pruto-nistrean în secolele II a.Chr-I p.Chr. Referatul tezei de doctor (Cluj Napoca).

\section{MUNTEANU 2004}

Munteanu, O., Lanțul slăbiciunilor sau unde au dispărut geţii. In: Arnăut, T./Munteanu, O./Musteață, S (eds.), Studio in Honorem Gh. Postică (Chișinău), 141-152.

MUNTEANU/IARMULSCHI 2005

Munteanu, O./Iarmulschi, V., Cultura Poieneşti-Lucaşeuca: repere cronologice, Analele ANTIM 6, 16-20.

\section{MÜLLER 1985}

Müller, R., Die Grabfunde der Jastorf- und Latènezeit an unter Saale und Mittelelbe (Berlin).

\section{NÉMETI 1989}

Németi, I., Necropola Latène de la Pișcolt, jud. Satu Mare (II), Thraco-Dacica X/1-2, 75-114.

POPOVICI 1981-1982

Popovici, R., Descoperirile din sec. III-II 1̂.e.n de la BornișNeamț, Cercetări Istorice 12-13, 153-158.

\section{POPOVICI 1988}

Popovici, R. Două piese vestimentare din secolele VI-VII descoperite la Borniș-Neamț, Arheologia Moldovei XII, 249252.

\section{POSTICĂ/ MUNTEANU 1999}

Postică, Gh./Munteanu, O., Aşezarea de tip PoieneştiLucaşeuca de la Orheiul Vechi, Cercetări Arheologice în Aria Nord-Tracă III, 457-494.

REINECKE 1988

Reinecke, A., Studien zur vorrömischen Eisenzeit im Umland der südlichen Ostsee. Forschungsstand-ChronologieKulturhistorische Beziehungen (ungedruckte Dissertation Berlin).

TEODOR 1980

Teodor, S., Aşezarea din epoca Latène de la Botoşana, Studii si Cercetări de Istorie Veche și Arherologie 31/2, 181-227.

\section{TEODOR 1987}

Teodor, S., Cercetările arheologice de la Ciurea, Arheologia Moldovei XI, 65-102.

TEODOR 1988

Teodor, S., Elemente celtice pe teritoriul est-carpatic al României, Arheologia Moldovei XII, 33-51.

TEODOR 1992

Teodor, S., Cercetările arheologice de la Lozna-Hlibicioc, jud. Botoşani, Arheologia Moldovei XV, 45-69.

VULPE 1953 
Vulpe, R., Săpaturile de la Poieneşti din 1949, Materiale și Cercetări Arheologice I, 213-506.

VULPE 1955

Vulpe, R., Le problème des Bastarnes à la lumière des découvertes archéologiques en Moldavie, Nouvelles étt. d hist. I, 103-119.

ZAHARIA/BURAGA 1979

Zaharia, E./Buraga, C., Cercetări de suprafață în comunele Dănești, Rebricea și Tăcuta (jud. Vaslui), Acta Moldaviae Meridionalis I, 241-268.

\section{ZANOCI 1998}

Zanoci, A, Fortificaţiile geto-dacice din spaţiul extracarpatic in secolele VI-III a.Chr. (Bucharest: Romanian Institute of Thracology).

ZIRRA 1997

Zirra, Vl. V., Contribuții la cronologia relativă a cimitrului de la Pișcolt. Analiză combinatorie și stratigrafie orizontală, Studii și Cercetări de Istorie Veche și Arherologie 48/2, 87-137.

ВИНОГРАДОВ/МАРЧЕНКО 2014

Виноградов, Ю. А./ Марченко, К. К., Северное Причерноморье в III в. до н. э. (взгляд из греческих государств), Археологические вести 20, 143-164.

\section{ЕРЕМЕНКО 1997}

Еременко, В. Е., «Кельтская вуаль» и зарубинецкая культура (Санкт-Петербург: Изд-во СанктПетербургского университет 1997).

КАЦ 2007

Кац, В. И., Греческие керамические клейма эпохи классики и эллинизма (опыт комплексного изучения), Боспорские исследованния XVIII (Симферополь-Керчь).

\section{ПАЧКОВА 1983}

Пачкова, С. П., Археологические исследования многослойного поселения у с. Горошова Тернопольской области. In: Смиленко, А. Т. (ред.), Археологические памятники Среднего Поднестровья (Киев), 4-55.

\section{ПАЧКОВА 2006}

Пачкова, С .П., Зарубинеикая культура и латенизированные культуры Европы (Киев: Институт археологии Национальной Академии Наук Украины).

ТЕЛНОВ/ЧЕТВЕРИКОВ/СИНИКА 2016

Телнов, Н. П./Четвериков, И. А./Синика, В., Скифский могильник III-ІІ вв. до н. э. у с. Глиное (Тирасполь).

ТКАЧУК 1999

Ткачук, М. Е, Гетика которую мы потеряли (из антологии хронологических разрывов), Stratum 3, 274-304.

ФЕДОРОВ 1960

Федоров, Г. Б., Население Пруто-Дневстровского междуречья в I т. н.э. Материаль и Исследование по Археологии 89 (Москва: Издательство Академии наук CCCP).

ЩУКИН 1994

Щукин, М. Б., На рубеже эр. Опьт историкоархеологической реконструкиии политических событий III в. до. н. э. - I. в. н. э. (Санкт-Петербург: Фарн). 


\section{Studies}

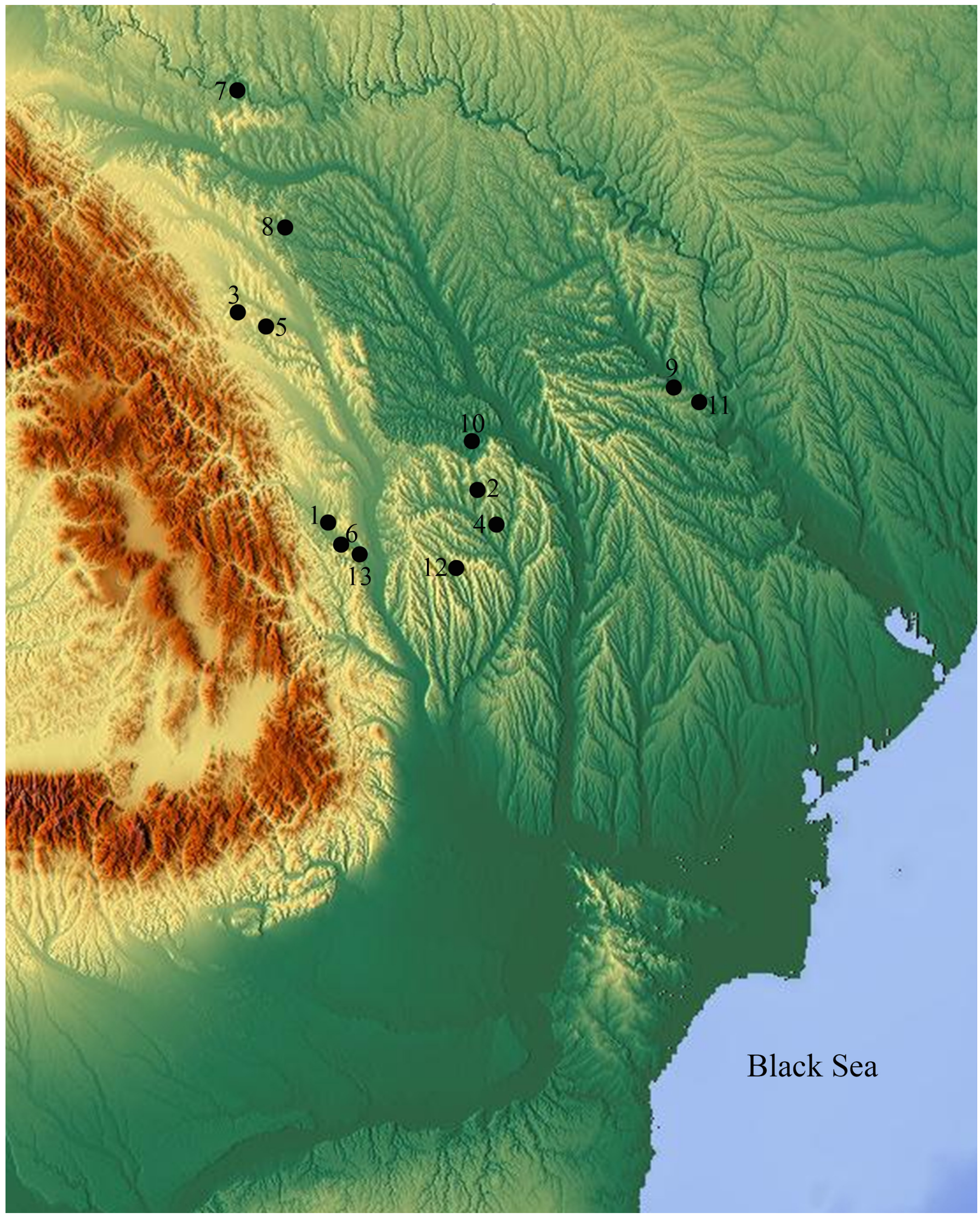

Fig. 1. Sites of Poienesti-Lucașeuca type mentioned in the text. 1 - Borniș, Neamt county; 2 - Borosesti, lași county; 3 - Botoșana, Suceava county; 4 - Dănesti La Meri, Vaslui county; 5 - Dolhestii Mari, Suceava county; 6 - Ghelăiești, Neamt county; 7 - Gorošovo, region Ternopol'; 8 - Lozna Hlibicioc, Botoșani county; 9 - Lucașeuca, r. Orhei; 10 - Lunca Ciurei, Iași county; 11 - Orheiul Vechi, r. Orhei; 12 - Poienești, Vaslui county; 13 -

Roșiori Dulcești, Neamț county. 


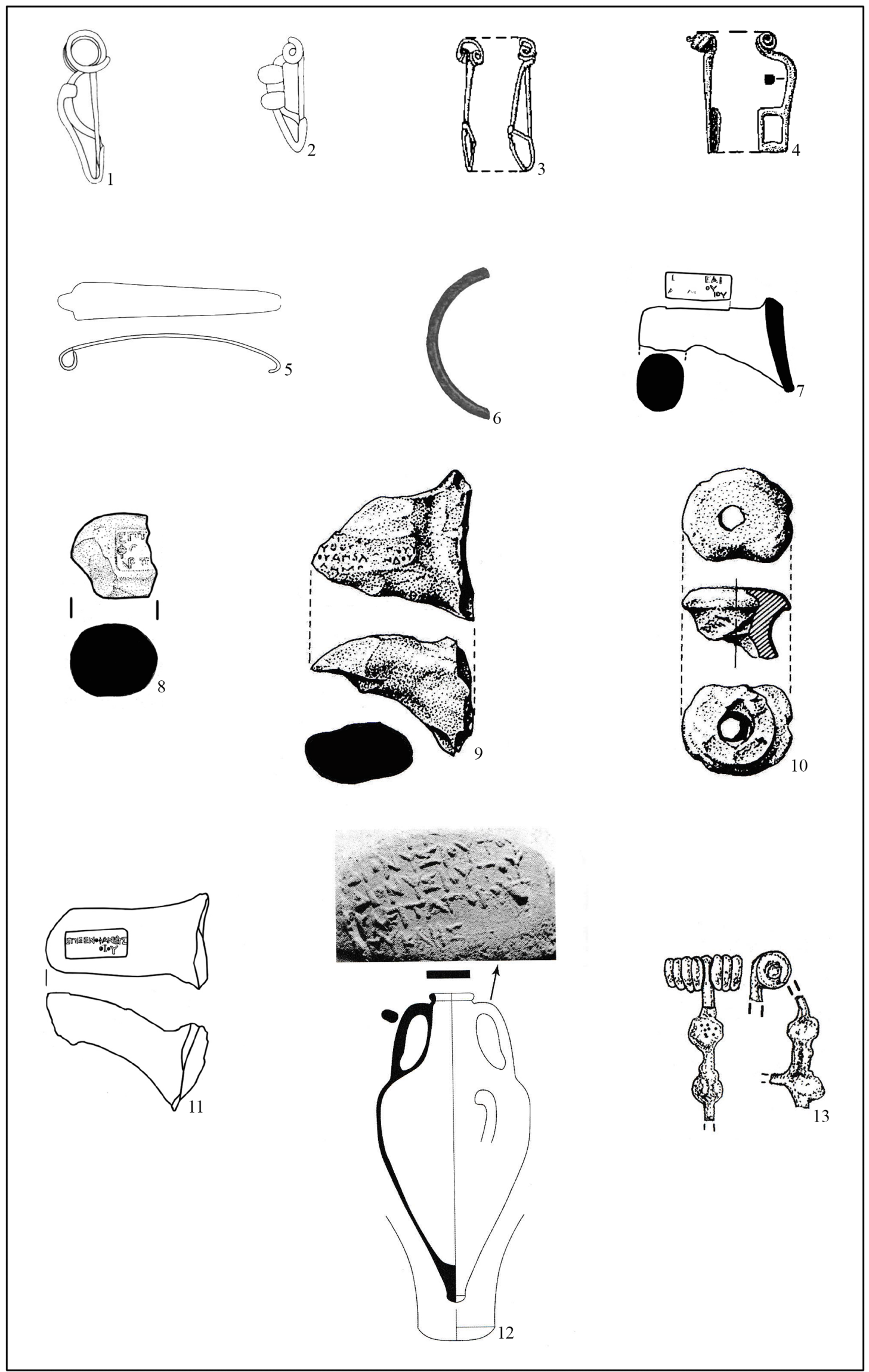

Fig. 2. Chronologically relevant items (various scales): 1 - brooch of type II.2; 2 - brooch of type II.5; 3 - the brooch at Dănești La Meri; 4 - the brooch at Borniș; 5 - belt fitting type III.3; 6 - the sapropelite bracelet at Gorošovo; 7-8 - stamped amphora handles from Lunca Ciurei; 9-10 - fragments of Greek amphorae discovered at Roșiori Dulcești; 11 - fragment of Rhodian amphora at Borniș; 12-13 - Synopean amphora and brooch with bow spheres in G31/1 at Hlinoie. 1-2.5 (after BABEȘ 1993); 3 (after TEODOR 1988); 4 (after POPOVICI 1988); 6 (after ПAЧKOBA 1983); 7-8 (after TEODOR 1987); 9-10 (after HÂNCEANU 2016); 11 (after POPOVICI 1980-1981); 12-13 (after ТЕЛНОВ/ЧЕТВЕРИКОВ/СИНИКА 2016). 